\title{
マイクロコイル状炭素繨維の気相合成とその特性
}

\author{
元島栖二, 岩永 浩*
}

(平成 8 年 8 月 28 日受理)

\section{Vapor Growth of Micro-coiled Carbon Fibers and the Properties}

Seiji Motojima and Hiroshi Iwanaga*

Department of Applied Chemistry, Gifu University,

1-1 Yanagido, Gifu 501-11, Japan

* Faculty of Liberal Arts, Nagasaki University, 1-14 Bunkyo-cho, Nagasaki 852, Japan

Micro-coiled carbon fibers (coils) were prepared by catalytic pyrolysis of acetylene at $650-850^{\circ} \mathrm{C}$, and growth conditions, morphology, growth mechanism and some properties were examined. The key points for obtaining coils with high coil yield were strict control of (1) kind of catalyst, (2) kind and flow rate of impurity gas, (3) reaction temperature, and (4) separation between source gas inlet and substrate. The most effective catalysts were $\mathrm{Ni}, \mathrm{Ti}$, and $\mathrm{W}$. The coils show an excellent electromagnetic shielding effect. TiC coils were obtained by vapor phase titanizing of the coils.

KEYWORDS : Carbon fiber, CVD, Acetylene, Coils, Thiophene, TiC fiber

\section{1. はじめに}

炭素繊維は, 先進複合材料の強化材として極めて重要で あり, PAN 系, ピッチ系の他, 気相成長炭素繊維 (VGCF) が合成されている。それらの繊維の形態はすべて直線状で ある。一方, 金属触媒存在下でアセチレンなどの炭化水素 を熱分解したり，COを不均化反応させると，時々コイル状 に巻いた炭素縅維が成長する1)-5)。しかし，その成長はかな り偶然的で再現性がなく, 詳細な合成条件や特性について はほとんど検討されていない。このようなマイクロコイル 状の繊維は, コイル状という特異的形態から発現される 種々の新規機能を応用して, 三次元強化複合材, 電磁波遮 蔽材, マイクロメカニカル素子, マイクロセンサー, 高温耐 食性クッション材・パッキング, マイクロフィルターなど,

岐阜大学工学部：テ501-11 岐阜市柳戸 1 番 1

$*$ 長崎大学教養部 : $\overline{7} 852$ 長崎市文教町 1-14
これまでの素材・材料では得られないような新規かつ高度 の機能を持つ次世代型新素材として幅広い応用が期待でき る。さらに, その特異的形態の成長メカニズムは, 学問的に も大変興味が持たれている。

著者らは最近, アセチレンを $7500^{\circ} \mathrm{C}$ 前後で金属触媒およ び不純物ガスの存在下で熱分解すると, マイクロコイル状 の炭素繊維がかなり再現性良く合成できることを見出し, その基本的な合成条件, 触媒, モルフォロジ一, 成長機構, 特性などについて検討し6)-13)，その一部はすでに, 1992 年 の本誌に紹介した14)。

本稿では, その後得られた結果を中心に, マイクロコイ ル状炭素䋐維（以下単にコイルと略す）の気相合成とその 特性について紹介する。

\section{2. 実験方法}

用いた代表的な反応装置を Fig.1 に示す。外熱式反応管 (透明石英製, 内径 $60 \mathrm{~mm}$, 長さ $1,000 \mathrm{~mm}$ ) の中央部の可 


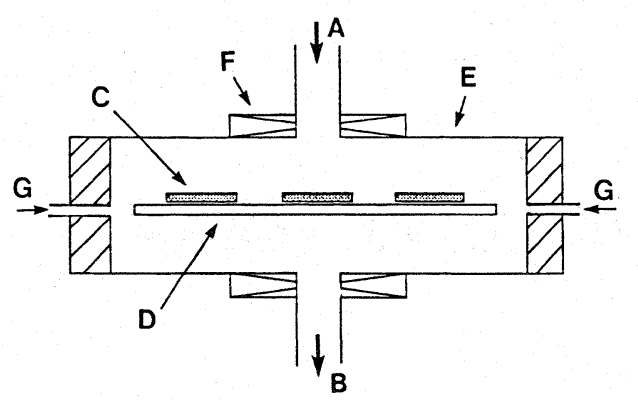

Fig.1 Schematic drawing of the apparatus for preparation of micro-coiled carbon fibers.

A) source gas inlet (acetylene+impurity gas + $\mathrm{H}_{2}$ ), B) gas outlet, C) substrate (graphite or metal plate, $\left.25 \times 25 \times 1 \mathrm{~mm}^{3}\right)$, D) susceptor (graphite), E) reaction tube (quartz, 60mm i.d.) , F) heater, G) Ar gas inlet.
動式サセプター（グラファイト製）上へ，金属粉末触媒を 塗布したグラファイト基板，ステンレスあるいは金属板 (触媒兼基板 $\left.\left(20 \times 20 \mathrm{~mm}^{2}\right)\right)$ をセットし, 上部原料ガス導 入口から原料ガスを基板表面に垂直に導入し, 排ガスを下 部より排出した。コイル収率は, 析出物からコイルのみを 顕微鏡下で分別, 秤量し, 原料として導入したアセチレン 中の炭素量に対する比で示した。

\section{3. 実験結果と考察}

\section{1 コイルの合成条件}

a）炭素源：アセチレン, エチレン, メタン, プロパン, ベンゼンなど種々の炭化水素について検討した。これらの 中で, アセチレンのみがコイル成長を示した。現在, VGCF の原料として一般的に用いられているベンゼンでは, いか なる条件下でもコイル成長はまったく観察されなかった。

b）触媒の種類とその形態：種々の遷移金属およびその化 合物について，チオフェンを不純物として用いた場合のコ イル成長に対する触媒効果を検討した。ただし, 硫化物の

Table 1 Metal catalysts and optimum reaction conditions. Impurity : thiophene.

\begin{tabular}{|c|c|c|c|}
\hline $\begin{array}{l}\text { Metal } \\
\text { Catalyst }\end{array}$ & $\begin{array}{l}\text { Optimum Reaction } \\
\text { Temperature }\left({ }^{\circ} \mathrm{C}\right)\end{array}$ & $\begin{array}{l}\text { Optimum Thiophene } \\
\text { Gas Flow Meter }(\mathrm{sccm})\end{array}$ & $\begin{array}{c}\text { Maximum Coil } \\
\text { Yield (\%) }\end{array}$ \\
\hline $\mathrm{Ti}$ & 775 & 0.47 & 54 \\
\hline $\mathrm{Zr}$ & 750 & 0.34 & 5 \\
\hline Hf & 800 & 0.48 & 7 \\
\hline $\mathrm{V}$ & 725 & 0.24 & 9 \\
\hline $\mathrm{Nb}$ & 750 & 0.42 & 26 \\
\hline $\mathrm{Ta}$ & 850 & 0.34 & 18 \\
\hline $\mathrm{Cr}$ & 700 & 0.24 & 23 \\
\hline Mo & 850 & 0.14 & 18 \\
\hline W & 750 & 0.45 & 55 \\
\hline $\mathrm{Mn}$ & 700 & 0.34 & 2 \\
\hline $\mathrm{Fe}$ & 800 & 0.40 & 8 \\
\hline Co & 850 & 0.14 & 11 \\
\hline $\mathrm{Ni}$ & 750 & 0.34 & 49 \\
\hline $\mathrm{MoS}_{2}$ & 800 & (Not addition) & 23 \\
\hline $\mathrm{NiS}$ & 750 & (Not addition) & 25 \\
\hline $\mathrm{TiC}$ & 775 & 0.45 & 14 \\
\hline $\mathrm{Ti}_{2} \mathrm{O}_{3}$ & 775 & 0.35 & 15 \\
\hline $\mathrm{Ti}^{* 1}$ & $775^{* *}$ & $0.47 * * *$ & 40 \\
\hline $\mathrm{Ti}^{* 2}$ & $775^{* *}$ & $0.47 * * *$ & 57 \\
\hline $\mathrm{Ti}^{* 3}$ & $775^{* *}$ & $0.47 * * *$ & 60 \\
\hline $\mathrm{Ti}^{* 4}$ & $775^{* *}$ & $0.47^{* * *}$ & 0 \\
\hline
\end{tabular}

$* 1)$ as reseived Ti metal plate, ${ }^{* 2}$ ) Ti plate oxidized in air at $650^{\circ} \mathrm{C}$ for $30 \mathrm{~min},{ }^{* 3)}$ Ti plate oxidized in air at $850^{\circ} \mathrm{C}$ for $30 \mathrm{~min},{ }^{* 4)}$ Ti plate aberaded by $\# 120$ emery paper following etching by $6-12 \mathrm{~N} \mathrm{HCl}$ of $50-80^{\circ} \mathrm{C}$ for $30-60$ min. $\left.{ }^{* *}\right)$ Temperature was fixed at $775^{\circ} \mathrm{C}$, ***) thiophene gas flow rate was fixed at $0.47 \mathrm{sccm}$. 
場合には，チオフェンは添加しなかった。コイル収率は，同 じ触媒でも，反応温度および不純物ガス流量に非常に影響 される。したがって, それぞれの触媒について, 最高のコイ ル収率が得られる最適の反応温度および不純物ガス流量で の触媒効果を比較検討した。結果を Table 1 に示す。ほと んどの遷移金属がコイル成長の触媒として有効であること が分かった。特に, Ni， Ti およびWが50\%以上の高いコイ ル収率を示し，優れた触媒であることが分かった。硫化物 では, $\mathrm{MoS}_{2}$ およびNiSが24〜35\%のコイル収率を示した。 炭化物では $\mathrm{TiC} か ゙ 14 \%$ 、また酸化物では $\mathrm{NiO}, \mathrm{Ti}_{2} \mathrm{O}_{3}$, $\mathrm{Ni}_{2} \mathrm{O}_{5}, \mathrm{WO}_{3}$ などが $15 \sim 20 \%$ の収率でコイル成長をもたら す事が分かった。市販のTi 板を未処理のまま用いた場合の コイル収率は $40 \%$ であるが, Ti 板を\#1200のエメリー紙で 十分研摩後, $50 \sim 80^{\circ} \mathrm{C}$ 濃塩酸でエッチングするとコイル はまったく成長しかった。この結果は, 金属表面の薄い酸 化物相が触媒作用に著しい影響を及ほすことを示唆してい る。触媒の形態としては, 平均粒径 $5 \mu \mathrm{m}$ の粉末が最も有効 であり, 平均粒径が $0.03 \sim 0.08 \mu \mathrm{m}$ の超微粒子では, コイ ルの最高収率は $10 \%$ 以下であった。以下の実験では, 特に 断らない限り, 触媒として $\mathrm{Ni}$ 粉末（平均粒径： $5 \mu \mathrm{m}$ ）を使 用した。

c）不純物ガスの種類と流量：VGCFの成長には，一般に イオウ不純物が触媒作用を示すと言われており, 多くの研 究者により直線状VGCFの成長に対するイオウ不純物の効 果, 成長条件, 成長機構などについて詳細な検討が行われ ている15)-21)。一方，コイル成長に対しては，イオウ不純物 の他, ホスフィン, 三塩化リンなどのリン系化合物も有効 である9)，11，12)。 Ni 粉末を触媒とし, 種々のイオウ系不純 物ガスを用いた場合の, 不純物ガス流量および反応温度に 対するコイル収率をFig.2 に示す。最も高いコイル収率（約 $50 \%)$ が得られるチオフェン不純物の最適流量は $0.35 \mathrm{sccm}$ (全ガス流量に対して $0.24 \%)$ で，この值から少しでもずれ るとコイル収率は急激に低下し， $0.02 \mathrm{sccm}(0.14 \%)$ 以下 あるいは $0.8 \mathrm{sccm}(0.57 \%)$ 以上では, コイルはほとんど 成長しなかった。他の不純物の場合にも, その最適ガス流 量の絶対值の違いはあるものの, 同様の傾向を示した。一

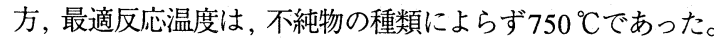
すなわち,コイルを得るためには, 不純物ガス流量および 反応温度を厳密に制御する必要があることがわかる。 Ni触 媒を用いた場合の種々の不純物ガスに対する最適ガス流量 および最適反応温度をまとめてTable 2 に示す。種々の不 純物ガスの中で, コイル収率および後で示すコイル形態の 点から, チオフェンが最も優れた不純物である。

d）反応温度：前項で述べたように, 反応温度の厳密な制 御は, コイル合成には不可欠の条件の一つである。一方, 最 適反応温度は, Table 1, 2からわかるように, $725 \sim 850^{\circ} \mathrm{C}$
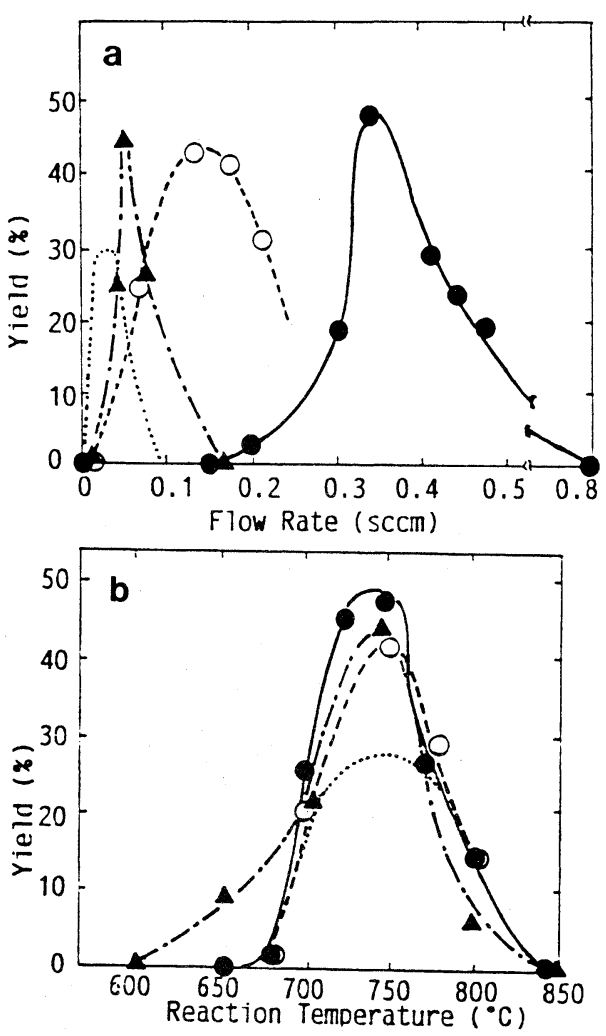

Fig.2 Effects of (a) impurity gas flow rate and (b) reaction temperature on the coil yield.

Catalyst : Ni. (O) thiophene, $(\Delta)$ tetrahydrothiophene, (○) methyl-thiophene, ( $\cdots)$ hydrogen sulfide. (a) reaction temperature : 750 ${ }^{\circ} \mathrm{C}$ 。(b) impurity gas flow rates : optimum gas flow rates at which the maximum coil yield is obtained (see Fig.2 a).

の比較的狭い範囲内にあることがわかった。

e）原料ガス導入口と基板との距離：Fig.3に, 原料ガス 導入口と基板との距離のコイル収量に及ほす影響を示す。 最短距離は, 装置形状の制約上 $7 \mathrm{~mm}$ とした。距離をこの約 倍の $15 \mathrm{~mm}$ とすると, コイルの析出量は $7 \mathrm{~mm}$ の場合と比較 して著しく減少した。距離が $25 \mathrm{~mm}$ (反応管の直径の約 1/2）では, 反応時間 30 分でもコイルはまったく析出せず, 炭素粉末のみが析出した。また, ノズル口を小さく絞り, 原 料ガスの線速度を上げるとコイル収率は増加した。以上の 結果から, カーボンコイル合成の基本条件の一つは, 原料 ガスの予熱時間をできるだけ短くして分解を防ぎ，生ガス に近い状態で触媒と接触させる事が重要と考えられる。 
Table 2 Impurity gases and optimum reaction conditions. Catalyst : Ni.

\begin{tabular}{|l|c|c|c|}
\hline \multicolumn{1}{|c|}{ Impurity } & $\begin{array}{c}\text { Optimum Reaction } \\
\text { Temperature }\left({ }^{\circ} \mathrm{C}\right)\end{array}$ & $\begin{array}{c}\text { Optimum gas flow } \\
\text { rate }(\mathrm{sccm})\end{array}$ & $\begin{array}{c}\text { Maximum Coil } \\
\text { Yield }(\%)\end{array}$ \\
\hline Hydrogen Sulfide & 750 & 0.04 & 30 \\
Thiophene & 750 & 0.35 & 50 \\
Methylthiophene & 750 & 0.15 & 43 \\
Tetrahydrothiophene & 750 & 0.07 & 45 \\
Butylmercaptan & 750 & 0.09 & 41 \\
Dietylsulfide & 750 & 0.10 & 34 \\
Carbon Disulfide & 750 & 0.04 & 36 \\
Phosphine & 650 & 0.01 & 45 \\
Phosphorus trichloride & 650 & 0.05 & 35 \\
Triethoxyphosphine & 650 & 0.08 & 35 \\
\hline
\end{tabular}

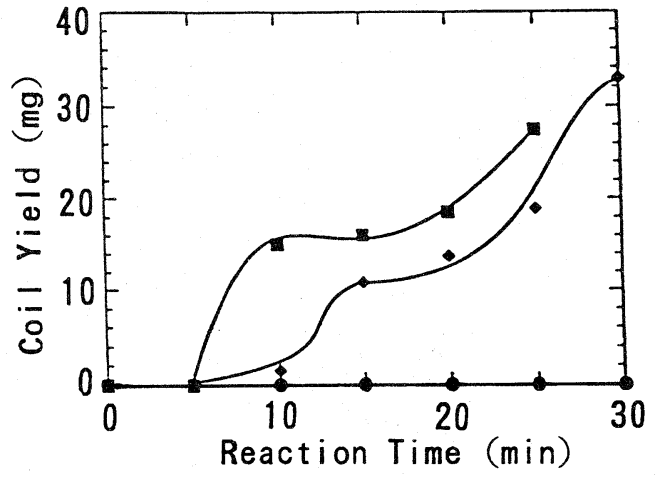

Fig.3 Effect of reaction time on the coil yield with respect to the separation between source gas inlet and substrate.

Reaction temperature : $750{ }^{\circ} \mathrm{C}$, gas flow rate : acetylene $90 \mathrm{sccm}$, thiophene $1.026 \mathrm{sccm}, \mathrm{H}_{2} 210$ $\mathrm{sccm}$, Ar $100 \mathrm{sccm}$. Separation of source gas inlet and substrate : () $7 \mathrm{~mm},(\diamond) 15 \mathrm{~mm}$, $25 \mathrm{~mm}$.

\section{2 モルフォロジー}

a) コイルの径およびピッチの制御：一般に, コイルのフ アイバー径は $0.03 \sim 0.3 \mu \mathrm{m}$, コイル径は $1 \sim 10 \mu \mathrm{m}$, コイル ピッチは $0.01 〜 1 \mu \mathrm{m}$ の範囲であった。Table 3 に触媒の 種類および形態の，コイルの平均成長速度およびコイル径 に及ぼす影響を示す。一般に，いずれの金属触媒でも，細か い研摩紙で磨いた金属板あるいは微粉末の方が, 粗い研摩 紙でみがいた金属板より，コイル径の小さなコイルが得ら れた。すなわち, コイル径は，用いる触媒の形態によりある 程度制御できる事が分かった。

b）コイルの成長速度：コイルの線成長速度は，一般に $0.5 \sim 1 \mu \mathrm{m} / \mathrm{s}$ であった。この值は, 直線状VGCF の值 22)-26
Table 3 Effect of metal catalyst morphology on the average growth rate and coil diameter of the coiled carbon fibers.

\begin{tabular}{|c|l|c|c|}
\hline \multicolumn{2}{|c|}{ Catalysis* } & $\begin{array}{l}\text { Average Growth Rate } \\
\text { of Coils }(\mu \mathrm{m} / \mathrm{s})\end{array}$ & $\begin{array}{c}\text { Diameter of } \\
\text { Coils }(\mu \mathrm{m})\end{array}$ \\
\hline \multirow{4}{*}{$\mathrm{Ni}$} & Plate (\#120) & $\sim 0.5$ & $5 \sim 6$ \\
& " (\#800) & $\sim 0.6$ & $5 \sim 6$ \\
& " (\#1500) & $\sim 1.0$ & $1 \sim 2$ \\
& Powder & $\sim 0.9$ & $2 \sim 3$ \\
\hline \multirow{2}{*}{$\mathrm{Ti}$} & Plate (\#120) & $\sim 2.5$ & $3 \sim 4$ \\
& Powder & $2.0 \sim 5.0$ & $1 \sim 2$ \\
\hline \multirow{2}{*}{$\mathrm{W}$} & Plate (\#120) & $\sim 1.0$ & $3 \sim 4$ \\
& Powder & $\sim 2.0$ & $1 \sim 2$ \\
\hline
\end{tabular}

* Metal plate catalysis was pre-abrassived by an emery paper, and the mesh number is shown in parenthesis.

より非常に小さい。

c）モルフォロジー： Ni-チオフェン系から得られたコ イルの代表的なモルフォロジーをFig.4に示す。ほとんどす ベてのコイルが，かなり一定のコイル径およびコイルピッ チで巻いている。特にFig.4 bでは極めて規則的に巻いて おり，長さが数 $\mathrm{mm}$ に達するものも容易に得ることができ た。Fig.5に種々の形状のコイルの拡大写真を示す。ほとん どのコイルは, DNAの二重らせん構造のように, 2 本のコ イルが互いに絡み合いながら巻き合って1本のコイルを形 成している（Fig.5 a)。ごくまれに，この二重らせんが， Fig.5 b e のように種々の形に変化し，アート的な美しい 姿をみせるコイルも観察された。コイルは，一般に二重コ イルであるが, 時にはFig.6のコイル破断面からわかるよう に, 二重コイル $\left(\mathrm{A}, \mathrm{A}^{\prime}\right)$ の内側にコイル径の小さな二重コ イル $\left(\mathrm{B}, \mathrm{B}^{\prime}\right)$ が入り,さらにその中により小さな二重コイ ル $\left(\mathrm{C}, \mathrm{C}^{\prime}\right)$ が入った，6重コイルも観察された。一般に，二 重コイルを形成している2本の単コイルの巻き方向は同じ で, 2 本共右巻きか左巻きのどちらかである。しかしごく希 には, Fig.7のように，2本のコイル（A,B）の巻き方向が 

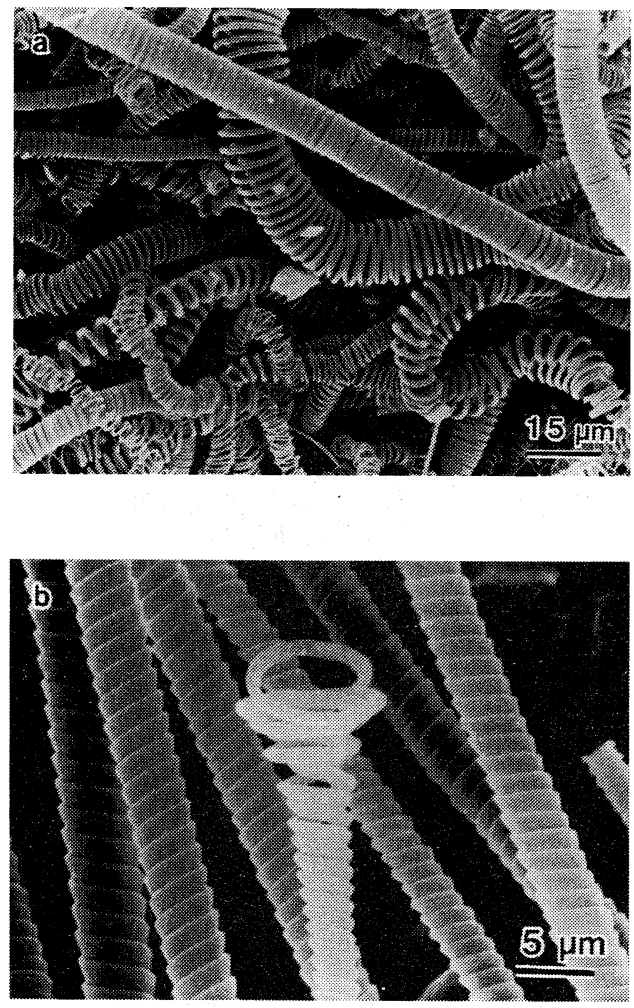

Fig.4 SEM image of (a) representative coiled carbon fibers and (b) very regularly coiled fibers.

まったく反対のコイルが互いに巻き合いながら，1本のコイ ルを形成しているものも観察された。バルクコイルの巻き 方向（右巻き，左巻き）の比率は，ほほ同じであった。

e）粉末状コイル：コイルは，硬い炭素質層の上に成長す るので，これをエメリー紙で研摩することにより，粉末状 のコイルを得ることができた。\#120のエメリー紙で研摩し て得られた粉末状コイル中のコイルの長さ分布をFig.8に 示す。ここで粉末を 5 回メッシュ篩でふるい, 合計を $100 \%$ とした。6〜 $10 \mu \mathrm{m}$ の長さのコイル分布が最も多いことがわ かる。

\section{3 成長機構}

気相から得られる直線状VGCFの成長機構については, Chitrapuら 27) をはじめ多くの研究者により提案されてる。 しかし，コイル状炭素纎維については, Amekinckx ら 28) がグラファイトナノチューブの成長機構を提案している以 外ほとんどない。我々は, コイルの成長機構として, 触媒粒 の各結晶面における炭素析出の大きな異方性に基ずくコイ ル化機構を提案した7)。Fig.9に, Ni 触媒を用い, 反応時間 30 秒で得られた死色の析出層表面の写真を示す。コイルの 成長初期には，この椂にすべてのファイバーが基板にほぼ
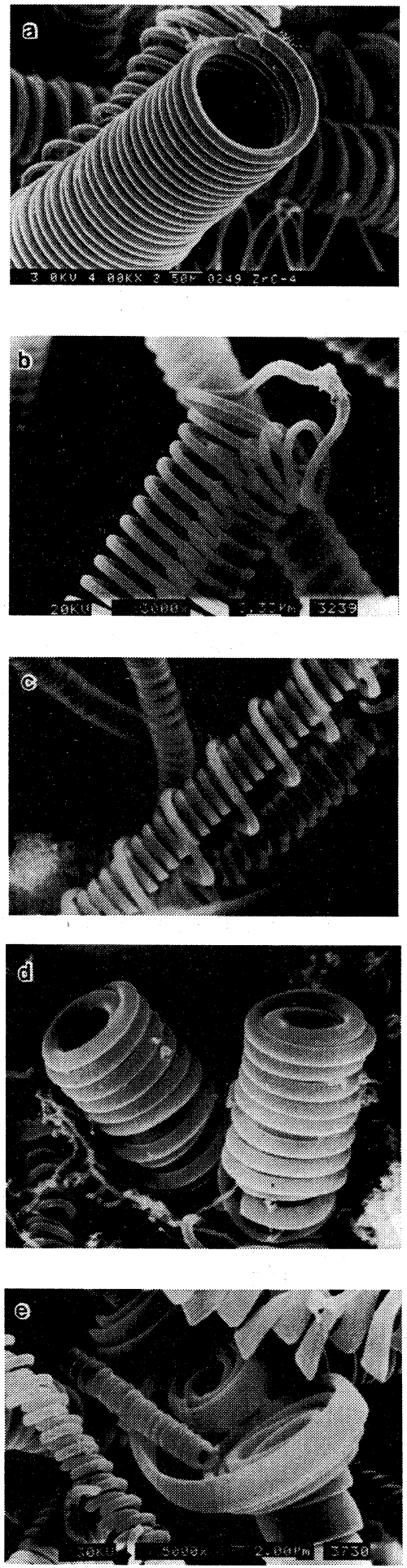

Fig.5 Enlarged view of the various coiling morphologies. 


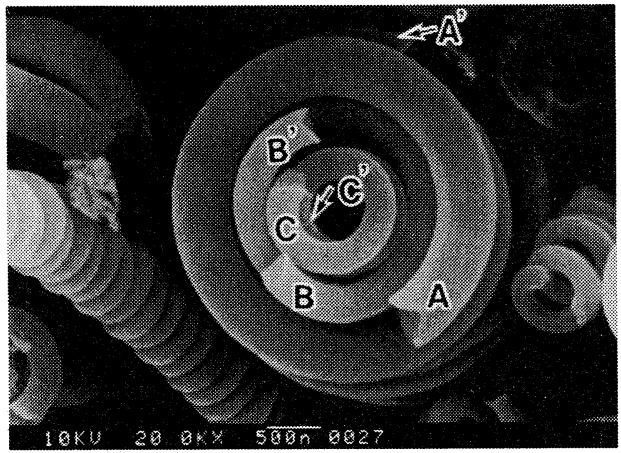

Fig.6 Six-folded coils.

$\left(A, A^{\prime}\right)$ outer double coils, $\left(B, B^{\prime}\right)$ intermediate double coils, $\left(\mathrm{C}, \mathrm{C}^{\prime}\right)$ inner double coils.

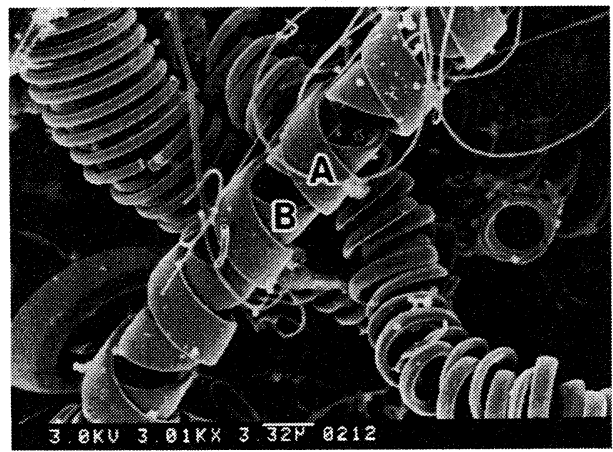

Fig.7 Double coils formed from A coil of counter clockwise and B coil of clockwise.

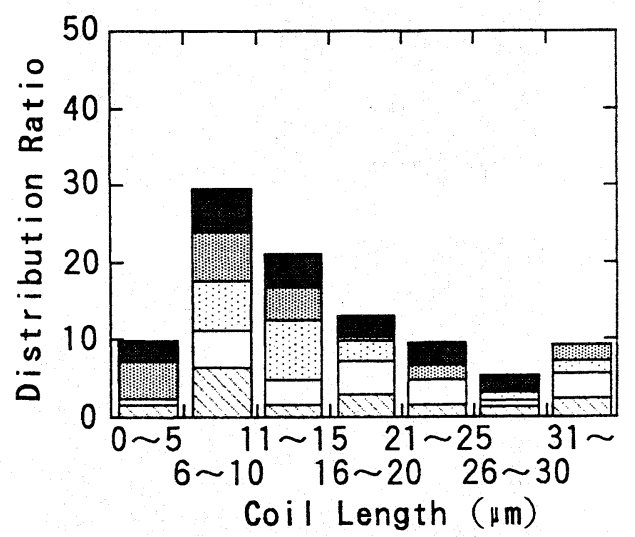

Fig.8 Distribution ratio of the coil length in bulk coils pulverized by emery paper (\#120) .
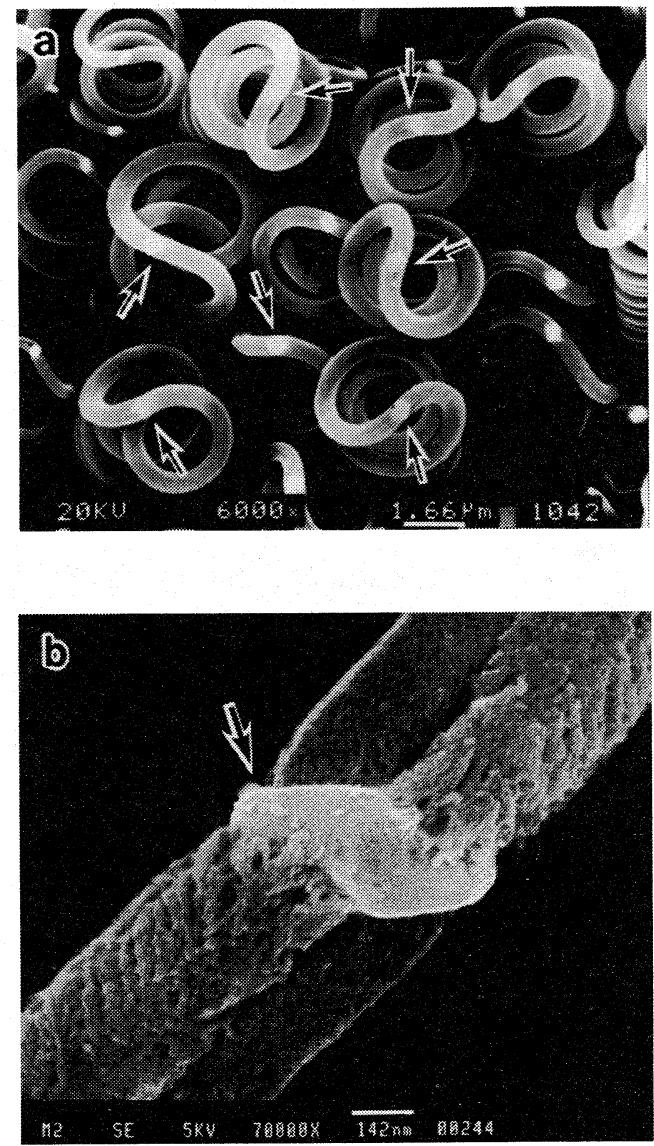

Fig.9 (a) Tip part of the coiled carbon fibers and (b) the enlarged view.

Reaction time : $30 \mathrm{sec}$. Arrows indicate a catalyst grain observed on the coil tip.

垂直に成長し，その先端部分には 8 の字状にループが形成 されており，ループの中心部には白く輝く部分 (矢印) が 観察された。Fig.9 bに，この白い部分の拡大写真を示す。 一般に菱形の明暸なファセットを持った結晶粒で，この部 分の粉末 $\mathrm{X}$ 線回折から, $\mathrm{Ni}_{3} \mathrm{C}$ 相 (Rhombohedral, R-3C) の存在が確認された。この相は，Fe触媒を用いて得られる 直線状VGCF の先端部分に観察される触媒粒の $\mathrm{Fe}_{3} \mathrm{C}$ 相に 相当している29)，30)。この部分の電子線回折図には, $\mathrm{Ni}_{3} \mathrm{C}$ 単結晶を示す明瞭なスポットが観察された（Fig.10）。した がって,この菱形粒の部分は, $\mathrm{Ni}_{3} \mathrm{C}$ 単結晶であり, これが コイル成長の実際の触媒作用をしているものと考えられる。 一方，この部分には, $\mathrm{Ni}$ およびCの他, $\mathrm{S}$ の存在が認められ た。しかし，X線回折からはニッケル硫化物相は確認され なかった。他の金属および金属化合物触媒を用いて得られ 

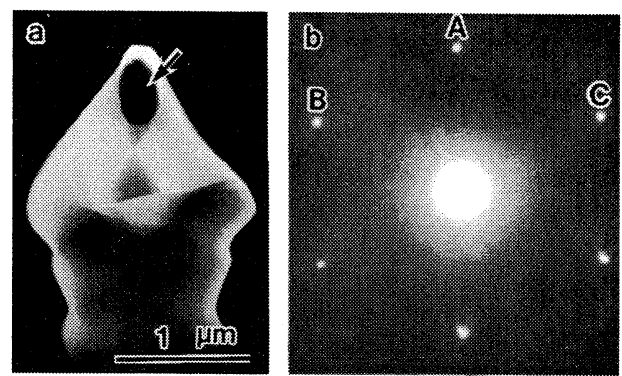

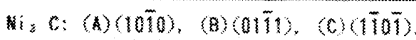

Fig.10 (a) TEM dark image and (b) selected area electron diffraction patterns. (A) (10ī0) for

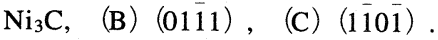

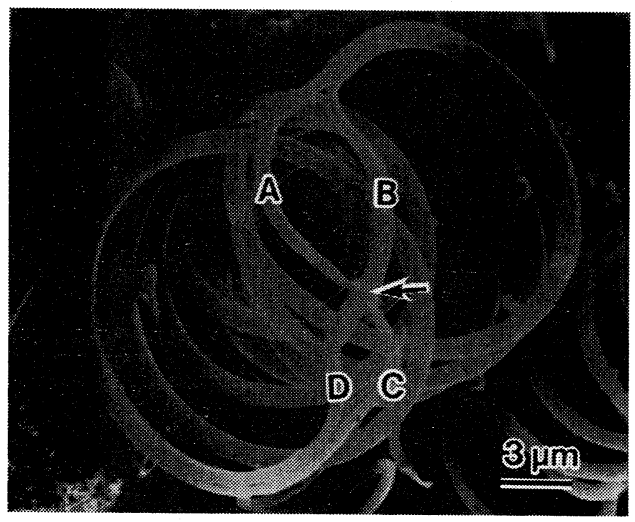

Fig.11 Tip part of the coiled carbon fibers.

Catalyst : $\mathrm{Nb}$, impurity : tetrahydrothiophene. An arrow indicate a catalyst grain.

たコイルの先端部分にも一般に触媒粒の存在が観察され， その中にはかなりの量のイオウの存在が認められた。しか し, これらの場合にも, X線回折からは金属硫化物相の存在 は確認されず, 非晶質相として存在しているものと考えら れる。金属触媒としてNbを，また不純物としてテトラヒド ロチオフェンを用いた場合, Fig.11のように，かなりコイ ル径の大きなコイルが得られた。また, 時々その先端部分 の触媒粒 (矢印) から4本のファイバーが成長し, 途中で2 本が融合して1本のファイバーとなり，その先でコイル状 に巻いた特異的形態が観察された。ファイバー $\mathrm{A}$ の融合点 までの長さは，Bのそれより明らかに長い。また，AとBが 融合後, 長い方のファイバー部分 (A) が外側に, 短い方 (B) が内側になるように巻いている。ファイバーC,D の場 合も同様である。コイル成長のメカニズムを探るため, そ の形態的な観察とともに, 3 種類の $\mathrm{Ni}$ 単結晶板を用いてコ
Table 4 Effect of Ni catalysts (single- and poly-crystals) on the deposition rate of total carbon and coil yield.

\begin{tabular}{|l|c|c|c|c|}
\hline & \multicolumn{3}{|c|}{ Crystal plane } & Polycrystal. \\
\cline { 2 - 5 } & $\mathrm{Ni}(100)$ & $\mathrm{Ni}(111)$ & $\mathrm{Ni}(110)$ & 23 \\
\hline $\begin{array}{l}\text { Deposition rate } \\
\text { of total carbon } \\
\left(\mathrm{mg} / \mathrm{cm}^{2}\right)\end{array}$ & 32 & 23 & 19 & 23 \\
$\begin{array}{l}\text { Coil Yield } \\
(\mathrm{mol} \%)\end{array}$ & 10.2 & 6.7 & 3.2 & 4.8 \\
\hline
\end{tabular}

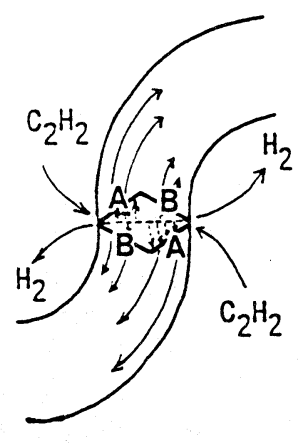

(a)

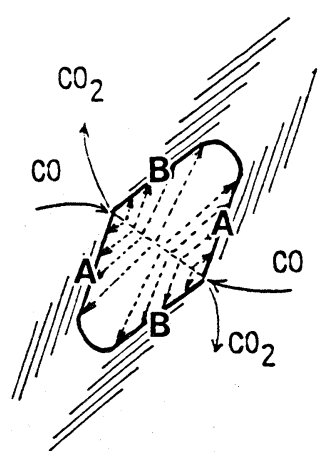

(b)
Fig.12 Growth mechanism of (a) the coiled carbon fibers and (b) straight VGCF. A and B indicate crystal planes of a catalyst grain.

イル合成を行い, 各結晶面での全炭素およびコイル析出の 異方性の有無の検討を行った。結果をTable 4 に示す。各 結晶面でのコイル収率は, $\mathrm{Ni}$ (100) に対しては $10.2 \% 、 \mathrm{Ni}$ (111) では $6.7 \%, \mathrm{Ni}$ (110) では $3.2 \%$ であった。すなわ ち，コイル成長は，結晶面の種類により著しい異方性があ る事が明らかにされた。この結果は，Ni触媒を用いメタン を $700{ }^{\circ} \mathrm{C}$ で熱分解した場合の直線状VGCF の成長順序 ; Ni (111) > (311) > (100) > (110）31），とは異なっている が, その理由は明らかではない。これらの結果から,コイル の成長は, 触媒粒の各結晶面での炭素析出速度の著しい異 方性が駆動力となって，コイル状に巻いて成長するものと 考えられる。すなわち, Fig.12（a）のように，A面での炭 素析出速度がB面より大きい場合, A,B 両面（実際にはも う一つC面が必要) から成長する1本の炭素繊維は, 図のよ うにカールしながら成長するであろう。これが繰り返され ることにより，Fig.13の（3），(4）を経てコイル状に成長 するものと考えられる。これまで提案されている直線状炭 素㵶維の一般的な成長モデル（Fig.12 b）においは，A,B 両面における炭素析出の異方性がないため, 直線状に成長 するものと考えられる。 


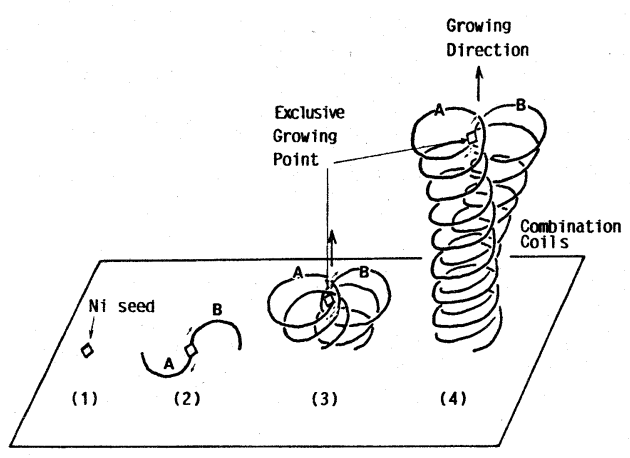

Fig.13 Growth process of the coiled carbon fibers.

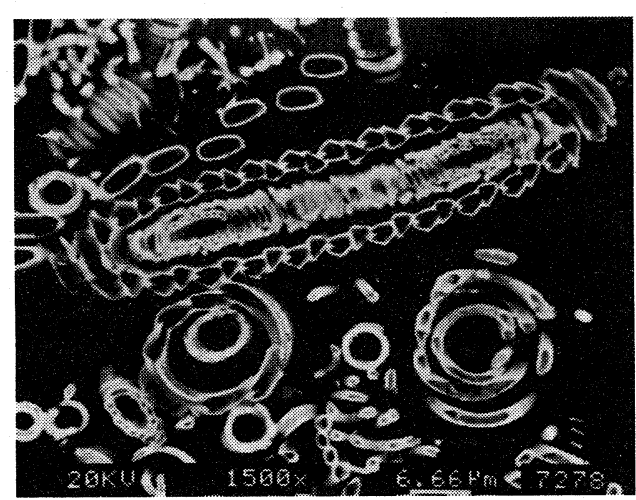

Fig.14. Polished cross section of the titanized coiled carbon fibers.

Reaction temperature : $900{ }^{\circ} \mathrm{C}$, reaction time : $120 \mathrm{~min}$

\section{4 コイル状の金属炭化物の合成}

コイル状炭素繊維は，高温で気相メタライジングするこ とにより，そのコイル形態を完全に保持したまま，対応す る金属炭化物コイルに変性することができる。例えば, $\mathrm{TiCl}_{4}+\mathrm{H}_{2}$ 雲囲気下で, $900 \sim 1200{ }^{\circ} \mathrm{C}$ で処理する事により, その表面の一部あるいは芯まで完全にチタナイジングされ たTiCコイルが得られた。Fig.14に, $900{ }^{\circ} \mathrm{C} て ゙ 120$ 分間于 タナイジングして得られた TiC 化コイルの鏡面研摩断面を 示す。表面に均一に TiC 層が形成されていことがわかる。

\section{5 微細構造および組成}

$1100{ }^{\circ} \mathrm{C}$ 前後で得られる直線状VGCFは，一般に非常に結 晶性が良く,グラファイト網面が瀻維軸に平行に発達した スクロール構造をしており，高い強度と弾性率を示す 24) 一方, コイルは, 合成温度が $750{ }^{\circ} \mathrm{C}$ 前後と比較的低く, X線 的には完全に非晶質である。Fig.15にas-grown およびAr

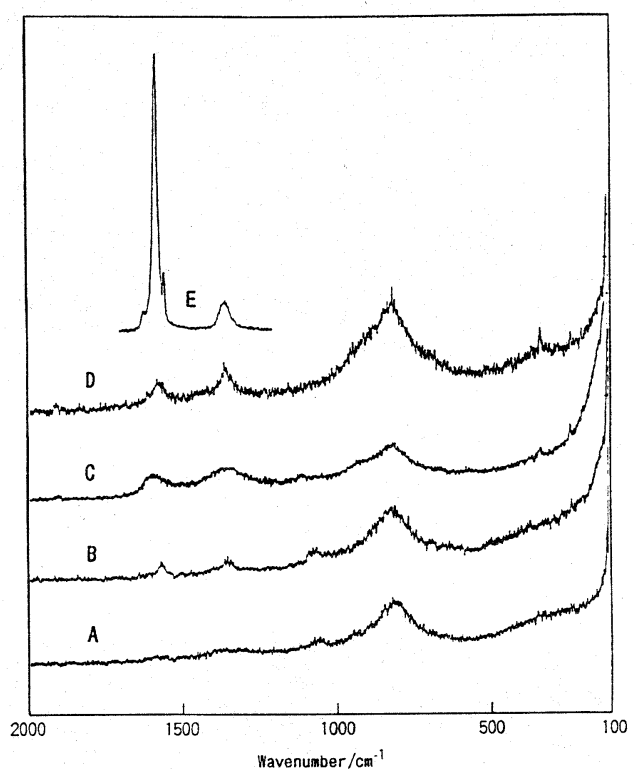

Fig.15 Raman spectra of (A) the as-grown and (B-D) heat treated coiled carbon fibers.

(A) as-grown coiled carbon fibers, (B) heat treated coiled carbon fibers at $2000{ }^{\circ} \mathrm{C}$ for $1 \mathrm{hr}$ in $\mathrm{Ar}$, (C) at $2000{ }^{\circ} \mathrm{C}$ for $20 \mathrm{hrs}$ in $\mathrm{Ar}$, (D) at $2800{ }^{\circ} \mathrm{C}$ for $1 \mathrm{hr}$ in $\mathrm{Ar}$, (E) graphite single crystal.

中で熱処理したコイルのラマンスペクトルを示す。asgrownのコイルでは, グラファイトに基ずくピ-クはほとん ど観察されない。また，これを $\mathrm{Ar}$ 中 $2000{ }^{\circ} \mathrm{C} て ゙ 20$ 時間，あ るいは $2800{ }^{\circ} \mathrm{C} て ゙ 1$ 時間熱処理してもグラファイトピークは かなりブロードであり，難黒鉛性であることがわかる。asgrown コイルは，炭素純度は97〜98\%で，そのほか $1 \%$ 前 後の水素および酸素が含まれていた。表面積は約 $300 \mathrm{~m}^{2} / \mathrm{g}$ とかなり大きな值を示した

\section{6 コイルの特性}

a）機械的特性：コイルは，完全弾性的に約 3 倍まで伸縮 する。さらに，ほぼ直線状まで (約4.5倍) まで延ばすこと ができるが，この場合歪みか残り元の長さの 1.5 倍までしか 戻らない。

b）電気的特性：as-grownのコイルは, $1 \mathrm{~S}^{-1} \cdot \mathrm{cm}$ オーダ 一の比抵抗を示し, その值はバルク密度の増加とともに減 少する。TiCコイルでは, これより1标低いバルク抵抗值を 示し, その值は $\mathrm{TiC}$ 化率およびバルク密度の増加とともに 減少した。

c）電磁波吸収特性：コイルの $12.4 \sim 18.0 \mathrm{GHz}$ の範囲の 


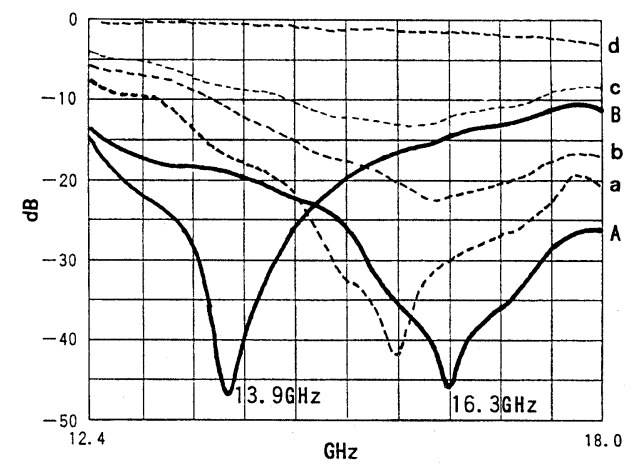

Fig.16 Electromagnetic shielding effect. (A) and (B) : coiled carbon fibers, $(\mathrm{a} \sim \mathrm{d})$ commercial graphite powders.

電磁波吸収特性を測定した。得られた結果をFig.16に示す。 ここで, 必要十分量のサンプルを得ることは現段階では困 難であったため, 約 $5 \mathrm{~g}$ (必要量の100分の1）を用いて子矠 実験を行った結果である。参考のため, 市販の種々のグラ ファイト粉末に対する值も示す。市販のグラファイト粉末 では, $15.7 \mathrm{GHz}$ でのみ強い電磁波吸収が認められるが，コ イル状炭素繊維では $13.9 \mathrm{GHz}$ および $16.3 \mathrm{GHz}$ の 2 か所で強 い吸収が認められた。種々のコイル形態および充分量のコ イルを用いれば全周波数領域で極めて強い電磁波の吸収が 期待できる事が分かった。

d）熱的性質：バルク密度 $0.0884 \mathrm{~g} / \mathrm{cm}^{2}$ のバルクコイルに 対して $0.0466 \mathrm{~W} / \mathrm{m} \cdot \mathrm{K}, 0.0562 \mathrm{~g} / \mathrm{cm}^{2}$ に対して $0.0562 \mathrm{~W} / \mathrm{m}$. Kであった。

\section{4. 結論}

種々の触媒および不純物ガス存在下で, アセチレンを熱 分解することにより, コイル状カーボンファイバー（コイ ル）を合成し, その詳細な合成条件, モルフォロジー, 成長 メカニズム, 微細構造, 特性などを検討した。その結果, コ イルを高い収率で得るためには, (1)炭素源, (2)触媒の種類, (3)不純物ガスの種類とその添加量 (流量) , (4)反応温度, (5) 原料ガス導入口と基板との距離などの合成条件を厳密に制 御する必要があることが分かった。コイルは, 高温で気相 メタライジングすることにより, 原料のコイル形態を完全 に保持したまま, 対応する金属炭化物コイルに変性するこ とができる。これらのマイクロコイルは, 理論的に最も理 想的な電磁波遮蔽材料であるといわれている。さらにその 特異的形態から発現される種々の新規機能を応用して, 広 範囲の応用が期待できる次世代型の新素材である。しかし, その研究は諸についたばかりであり, 今後の発展を大いに 期待したい。

\section{謝辞}

バルクコイルの電磁波吸収特性は, ペンシルバニア州立 大学のV. K. Varadan教授に測定していただいた。記して 感謝する。

\section{文 献}

1) J. Caluszka and M. H. Back, Carbon 22 (1984) 141.

2) M. Audier and M. Coulon, Carbon 23 (1985) 317.

3) 岡田芳樹, 池田 茂, 豊田浩一, 竹内一夫, レーザー研 究 No.13 (1991） 98-101.

4) Y. Okada and K. Takeuchi, J. Materi. Sci. Lett. 11 (1992) 1715-1717.

5) W. B. Downs and R. T. K. Baker, Carbon 29 (8) (1991) 1173-1179.

6) S. Motojima, M. Kawaguchi, K. Nozaki, and H. Iwanaga, Appl. Phys. Lett. 65 (1990) 321.

7) M. Kawaguchi, K. Nozaki, S. Motojima and H. Iwanaga, J. Cryst. Growth 118 (1992) 309-313.

8) H. Iwanaga, M. Kawaguchi and S. Motojima, Jpn. J. Appl. Phys. 32 (1993) 105-115.

9) S. Motojima, I. Hasegawa, S. Kagiya, M. Momiyama, M. Kawaguchi and H. Iwanaga, Appl. Phys. Lett. 62 (19) (1993) 2322-2323.

10) S. Motojima, Y. Itoh, S. Asakura and H. Iwanaga, J. Mater. Sci. 30 (1995) 5049-5055.

11) S. Motojima, I. Hasegawa, S. Kagiya, K. Andoh and H. Iwanaga, Carbon. 33 (8) (1995) 1167-1173.

12) S. Motojima, S. Kagiya and H. Iwanaga, Mater. Sci. Eng. B34 (1995) 47-52.

13) S. Motojima, S. Asakura, T. Kasemura, S. Takeuchi, and H. Iwanaga, Carbon, 34 (3) (1996) 289-296.

14）元島栖二, 川口雅之, 岩永 浩, 炭素 151 (1991) 41-50.

15) T. Kato, K. Haruta, K. Kusakabe and S. Morooka, Carbon 30 (1992) 989.

16) M. S. Kim, N. M. Rodriguez and P. T. K. Baker, J. Catal. 143 (1993) 449.

17) W. T. Owens, N. M. Rodriguez and P. T. K. Baker, Catalysis Today, 21 (1994) 3.

18) W. T. Owens, M. S. Kim, N. M. Rodriguez and R. T. K. Baker, in "Catalyst Activation" (Edited by B. Delmon and G. F. Froment, Elsevier Science, 1994), p.191.

19）松本正文, 橋本敏清, 村田勝英, 後藤繁雄, 化学工学論 文集 18 (4) (1992) 389-393. 
20）後藤繁雄，ケミカル・エンジニヤリング，1991 年12月 号, pp.23-28.

21）加藤貴史, 草壁克己, 諸岡成治, ケミカル・エンジニヤ リング，1990年11月号, pp.67-71；1991年1月号, pp.74-77.

22) T. Koyama, M. Endo and Y. Onuma, Jpn. J. Appl. Phys. 11 (1972) 445.

23) M. Endo, M. Shibata, T. Momose and M. Shiraishi, in 17th Carbon Conf. 19 (1981) 148.

24) M. Endo, Chemtech September 1988, pp. 568- 576.

25) S. R. Mukai, T. Masuda, Y. Fujikata, T. Harada and K. Hashimoto, Carbon 33 (5) (1995) 733-736
26) 向井 紳, 増田隆夫, 原田武志, 橋本健治, 化学工学, 60 (7) (1996) 481-482.

27) P. Chitrapu, C. R. F. Lund, and J. A. Tsamopoulos, Carbon 30 (2) (1992) 285-293.

28) S. Amelinckx, X. B. Zhang, D. Bernaerts, X. F. Zhang, V. Ivanov and J. B. Nagy, Science 265 (1994) 635.

29) A. Oberlin, M. Endo and T. Koyama, J. Cryst. Growth 32 (1976) 335.

30) M. Endo and T. Koyama, Synthetic Metal 3 (1981) 117.

31) R. T. Yang and J. P. Chen, J. Catal., 115 (1989) 52.

\section{日本学術振興会炭素材料第 117 委員会第238 回委員会}

1. 日 時: 平成 8 年7月26日 (金)

2. 場 所：中央大学駿河台記念館

3. 提出資料：

117-238-A-1 アモルファスカーボンフィルムの透過電子顕微鏡像の画像解析

押田京一 (長野高専)

小林 稔, 吉田照実, 箕浦史登, 遠藤守信 (信州大·工)

117-238-B-1 ディスオーダー炭素への電気化学的 Li 吸蔵挙動 (1)

辰巳国昭，澤田吉裕（大工研）

河村寿文, 細坪富守 (ペトカ)

117-238-B-2 リチウムイオン二次電池負極材料としての表面修飾炭素-窒素化合物

中島 剛, 高明天 (京大·工)

117-238-C-1 Crack-face bridging : Finite element analysis, analytical model, and experimental result J.W.Cao and M.Sakai (Toyohashi Univ. of Technology)

117-238-C-2 炭素複合材の微小硬さに及ぼす荷電粒子と $14 \mathrm{MeV}$ 中性子照射効果の実験的研究 馬場信一, 石原正博, 衛藤基邦 (原研) 